\title{
Best of Ten: \\ Reengineering Makes Industry Meaningful in College
}

\author{
Dorene Perez, Jim Gibson, Rose Marie Lynch \\ Illinois Valley Community College
}

An entrepreneurial project at Illinois Valley Community College immerses engineering design and electronics students in reengineering over the entire course of their two-year technical programs.

The four-semester program brings freshmen engineering and electronics students into the continuous quality improvement loop in their first semester courses where they analyze and recommend improvements on products previously designed and produced by student teams. In their second semester, the engineering and electronics students fine-tune the product redesigns, and freshmen CAD students complete the set of working drawings.

In their third semester, the CAD design students create models and, working with electronics students, create prototypes of the redesigned products.

In the fourth semester, the project culminates with the addition of business students and the formation of student teams or "companies," which manufacture, market and sell the products. The engineering design, electronics and business classes are scheduled at a common time to allow the student "companies" to meet. Integrating students from various disciplines not only fulfills the technical needs of the project, but also provides valuable interaction and communication opportunities.

This entrepreneurial Reengineering Makes Industry Meaningful In College program not only exposes students to the world of industry within the confines of the classroom, it is a replicable, cost-effective model that can be adapted to a varying number of semesters and integrated into a variety of technical programs and college settings.

\section{The origin of entrepreneurship in engineering and electronics at IVCC}

Ten years ago, the engineering design instructor and a business instructor at Illinois Valley Community College developed a creative plan to provide their students with workplace, entrepreneurial experiences. As a project in one of their courses, the instructors integrated their students into teams to develop, produce and sell a product. They named the project Making Industry Meaningful In College or MIMIC. A few years later the technical side of the teams expanded when electronics students were added to the project. The business side also expanded, and a MIMIC business course was developed as a capstone for students in Associate in Applied Science degree programs in marketing, accounting, management, computer systems and information systems.

\section{Proceedings of the 2005 American Society for Engineering Education Annual Conference \& Exposition} Copyright $(\mathbb{C}$ 2005, American Society for Engineering Education 
The MIMIC project successfully addressed a problem the technical programs faced -providing students with workplace experiences. IVCC is located in a rural and primarily agricultural district in north central Illinois. As a result of a limited industrial base, a limited number of engineering and technology jobs are available in the district, posing problems for students seeking internships and for the college seeking industry partnerships. Technical jobs, however, are readily available just outside of the college district; Chicago, Rockford and Peoria are all within 60 to 100 miles of the IVCC campus. By providing simulated world of work experience on the campus, MIMIC provided a solution to the technical programs' dilemma.

In the first ten years of the MIMIC project, the entire process was completed in one semester, including:

- Assigning students to multidisciplinary "companies,"

- Providing training in project management, teamwork, problem solving, critical thinking and communication skills,

- Choosing, designing, prototyping, manufacturing, marketing and selling products.

While the project successfully provided teamwork, communication and entrepreneurship experiences, the limited time frame did not allow students to absorb the training, design viable products, and experience CQI methodology. Expanding the program for the engineering and electronics students solved those problems. Additionally, this four-semester program replicates the industry process more closely. In the original one-semester project, the engineering design students were responsible for creating the design, prototyping, modeling and completing the working drawings. In the expanded program, the students who create the original design, pass those designs on to other students who prototype and model and complete the working drawings.

\section{The project today}

Today, Reengineering Makes Industry Meaningful In College embeds CQI methodology throughout the two-year engineering design and electronics curricula and culminates in the entrepreneurial MIMIC project.

Semester one: Students in the beginning CAD course, Computer Aided Drafting I, which is required of both engineering design and electronics students, are introduced to CQI principles. The students break down and analyze products built by student teams in previous semesters and make recommendations for improvement on those products. Based on those recommendations, students enrolled in Engineering Graphics I, prepare preliminary drawings of redesigns. Engineering Graphics I is a course designed for transfer to a four-year engineering program.

Semester two: Students in the second CAD course, either Computer Aided Drafting II or Electronics Drafting, continue to study the CQI loop. They complete the set of working drawings on the redesigned products.

Proceedings of the 2005 American Society for Engineering Education Annual Conference \& Exposition Copyright $\mathbb{C}$ 2005, American Society for Engineering Education 
Semester three: Students in the third CAD course, Computer Aided Design, continue to study CQI principles. They prepare models to be printed to a rapid prototyping machine and produce prototypes of the redesigned products.

Semester four, MIMIC: Students in Design Projects, Linear Electronics, and a business course designed for the MIMIC project are assigned to multi-disciplinary teams to manufacture, market and sell the products that were prototyped the previous semester. This entrepreneurial component provides the student teams, called "companies," with a simulated industrial setting. The engineering design students in the Design Projects course act as project managers for their "companies."

This two-year reengineering program was phased in to allow as much participation as possible and to provide reengineered products for the student companies in the first year the program was in place. Product analysis, redesign and prototyping was completed in one semester, providing reengineered products for the student companies formed in the spring 2005 semester. The full, four-semester program will be in place for the 2005-2006 academic year.

\section{Products previously created by student companies}

Over the last ten years, student teams had one semester to select, design, prototype, produce and sell their products. The teams decided what they would produce, subject to approval by the MIMIC instructors. Based on a proposal the student teams submitted online, the engineering and electronics instructors evaluated the feasibility, design intent, functions, specifications and capability for manufacturing and assembly on campus. The business instructor evaluated marketability and cost factors. Approval from all three instructors was required. Typical products included security devices, desktop water fountains, electronic games, lamps, clocks and lighted picture frames.

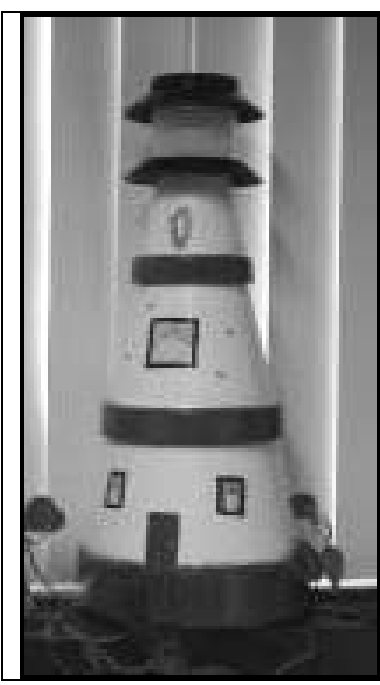

The lighthouse, at left, was a student product intended as a yard ornament. It incorporates a solar-powered light. Constructed of clay pots, the lighthouse is 18 inches tall.

The butterfly-shaped clock, at right, was one of several shapes

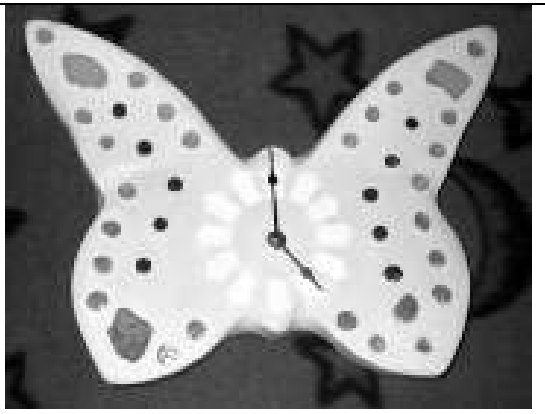
and sizes produced by a student company. Each of the batteryoperated clocks is decorated with chips of stained glass held in place by a grout mold. The mold shapes were designed by the CAD students on that team 


\section{Student products being reengineered}

Products previously manufactured and sold by student teams are now being reengineered, not only to incorporate newer technology but also to improve the original design, functions, components, cost and ease of production. More products are reengineered than needed for the student companies, allowing the instructors to select the best of the redesigned products for manufacture and sale.

As the strobe light (below) illustrates, the reengineering is improving the quality of the products. More importantly, students are immersed in the continuous quality improvement process throughout their technical programs.

The strobe light on the left is
the original product that was
designed, produced and sold
by a student team several
years ago. The light on the
right is the reengineered
product, redesigned for
manufacturing and sale in
spring 2005.
The original product, well
designed for its time,
predates the students' access
to a rapid prototyping
machine and mold making
capability. For aesthetic
purposes, the students taped
over the glue that held the
plastic box together. Newer
technology and reengineering
allowed the students to create
the more commercially viable
and professional product on
the right.

The new design is also more effective. The original design concentrated light in one direction, upward from the box. The new design distributes light more evenly throughout a room because the upper section is made of clear plastic.

In the electronic features, the RC time constant in the new design was altered to affect the time charge rates, which affects the flash rates. The new design includes a straight xenon tube, replacing a u-shaped one in the original design, and the circuit board was repositioned to accommodate the other design changes.

Proceedings of the 2005 American Society for Engineering Education Annual Conference \& Exposition Copyright (C) 2005, American Society for Engineering Education 


\section{The entrepreneurial component: Integration of business students}

The business students who participate in MIMIC, the entrepreneurial component, are enrolled in a capstone course, Integrated Business Operations, required in their Associate in Applied Science degree programs. They are from a variety of career fields, including marketing, accounting, management, computer systems and information systems, which allows the makeup of the "companies" to be representative of an industry. Integrating students from various disciplines not only fulfills the technical needs of the student teams but also provides valuable interaction and communication opportunities. Acting on the advice of the advisory committees for their career programs and utilizing a list of essential workplace skills ${ }^{1}$ endorsed by the area Tech Prep consortium, the instructors who organize the project make the development of teamwork and communication skills a major focus. In their technical courses, the engineering and electronics students do work in teams and communicate with other technical students. In their companies, however, the students experience how people in other disciplines think and work, and they are encouraged and trained to adapt and communicate more effectively with people outside of their disciplines. Ten years of experience with the original MIMIC project continued to reinforce the need for such training and practice.

\section{The entrepreneurial component: Organization and scheduling}

For the entrepreneurial, MIMIC semester, when products are manufactured and sold, the students' courses are scheduled at a common time to allow for company meetings and training sessions as needed. Those courses are:

- Design Projects, a capstone course which enables students to use their skills to design products for production and supervise production as project managers.

- Linear Electronics, a course which focuses on analysis of electronic component design, application, and construction with and methods of interfacing linear integrated circuits.

- Integrated Business Operations, a capstone course which offers students credit for the business side of the student companies.

Before the semester begins, the instructors evaluate the redesigned products, not only for the quality of the redesign, but also for the cost, ease of production and marketability. With more products redesigned than needed for the student companies, some redesigned products are not selected for production.

The semester begins with the three instructors assigning students into their companies and assigning each company to a product. Enrollment determines the number of companies and how many students from each discipline are in each; typically a company includes two engineering design students, two electronics students, and a mix of students from the various business fields. Where possible, when a student in one of the companies has worked on a redesign of a selected product, that product is assigned to the student's company.

Proceedings of the 2005 American Society for Engineering Education Annual Conference \& Exposition Copyright (C) 2005, American Society for Engineering Education 
Companies meet immediately for orientation and for training. Instructors from other disciplines are brought into the company meetings or into the individual courses, as consultants would be in a business or industry setting, to teach workplace skills such as teamwork, goal setting, problem solving, critical thinking and communication skills. While certain training sessions are routinely provided, others are added based on the needs of the students and student companies that semester.

Communication channels, including e-mail and WebBoard, are established to allow students to conduct their company business realistically; students must prepare agendas, take and disseminate notes of meetings, for example.

During the weekly meetings that follow, companies decide on a product name and corporate name and training in various workplace skills continues. While the engineering design students act as project managers, students assume responsibility for a portion of the project based on their discipline: marketing students survey potential buyers to gauge product and pricing preferences and research any competition, accounting students start on production budgets, business students plan the fair where the products will be sold. Students also assume responsibility for facilitating company meetings on a rotation basis.

The student teams research and purchase materials and determine the final selling price. A minimum of one week is devoted to producing the products with the students in all of the disciplines required to participate. The number of units to be produced is set by the instructors. Marketing students design packaging, and prepare the written instructions for assembly and/or operation of the products by working with students in a technical writing class.

Business students are in charge of scheduling, planning, picking a theme, promoting and setting up an end-of-semester MIMIC Fair where the products are sold. All of the students assist in the sale of their company's product at that on-campus event. The final work on the project is completed by accounting students who prepare a cost analysis of the sales at the fair, which culminates in a recommendation on the commercial viability of each product.

The entrepreneurial, MIMIC component wraps up with a celebration dinner for all participants with awards and certificates presented to the students.

\section{The entrepreneurial component: Communication exercises}

A number of communication exercises are integrated into the entrepreneurial, MIMIC semester. In addition to the small group communication skills required for the student companies to function successfully, the students complete other types of communication exercises that would be required of them on the job. All of the students give oral presentations in a 120-seat, multi-screen, electronic lecture hall. In addition to the student teams, the audience includes members of the faculty and administration. The presentations are scheduled throughout the semester with students from each discipline explaining their portions of the project. Engineering students, for example, defend the product designs early

Proceedings of the 2005 American Society for Engineering Education Annual Conference \& Exposition Copyright $\mathbb{C}$ 2005, American Society for Engineering Education 
in the semester; and accounting students defend their recommendations at the end of the semester.

The types of written materials produced by the students are determined by their discipline. Engineering students detail the product designs in formal, technical reports. Marketing students create sales slogans, advertising materials and product descriptions. Business students prepare notes of company meetings and send invitations and thank you messages to faculty who serve as consultants.

\section{Evaluation and assessment of the project}

Since the one-semester MIMIC project was expanded to a four-semester program beginning in fall 2004, a full assessment of the impact of the program will not be possible until the first group of freshmen have completed their technical programs. An examination of the products redesigned in the fall of 2004 (see strobe light example above) is a clear indication that product quality and viability has improved even in one semester. As the program continues, students in the reengineering program and the MIMIC project itself are being evaluated from a number of perspectives.

In the semesters before the entrepreneurial component:

- Instructors evaluate student analyses of products and recommendations for redesign,

- Instructors evaluate redesigns and working drawings,

- Instructors evaluate the final drawing package.

- Instructors evaluate models and prototypes.

During the entrepreneurial, MIMIC semester:

- Instructors evaluate teamwork and communication skills.

- Instructors evaluate marketing surveys, promotional plans and materials, accounting reports and financial plans.

- Consulting instructors assist in evaluations or oral reports, written reports, e-mail and memos.

- Potential buyers evaluate products.

At the conclusion of and following the entrepreneurial, MIMIC semester:

- Students provide feedback on their teams, on the training provided by the consulting instructors and on the entrepreneurial project.

- Technical students provide feedback about the four-semester program.

- Business and industry leaders provide feedback on the products, program and graduates.

In the past, business and industry leaders have been overwhelmingly supportive of the onesemester MIMIC project because it prepares students for the workplace by giving them handson experience dealing with workplace problems. 


\section{Funding for Reengineering Makes Industry Meaningful In College}

The only funding required for the four-semester program is for the one-semester entrepreneurial or MIMIC component. In Spring 2005, that budget was approximately $\$ 3,000$ :

- $\$ 400$ stipend for the engineering design, electronics and business instructors, for a total of $\$ 1,200$.

- $\$ 1,000$ for product supplies.

- Under $\$ 1,000$ paid to other IVCC instructors for providing training in teamwork and other workplace skills.

Since its inception, the MIMIC project has been sponsored by the college's Tech Prep team, and the funding is from a mini-grant provided through Carl D. Perkins federal legislation. Product sales, from previous years, covered some additional expenses for supplies and end-ofproject recognition for the students.

For product supplies, each student company is allocated a budget determined by the number of companies formed that semester. Instructors, acting as consultants, are paid $\$ 75$ or $\$ 50$ for a one-session exercise depending on whether the exercise is new or a repeat.

\section{Adaptability of Reengineering Makes Industry Meaningful In College}

Reengineering Makes Industry Meaningful In College was designed for four-semester technical programs at a community college, but the concept is adaptable to a varying number of semesters in a variety of college settings. The concept could be developed in two semesters, for example, with the reengineering components in the first semester and entrepreneurial components in the second. The reengineering components in semester one could include product analysis, recommendations and redesign; prototyping could be in either semester.

The program can be adapted to various college settings, including university programs, by adjusting the complexity of the products to match student backgrounds and instructor/course/program expectations. Programs that incorporate aspects of Reengineering Makes Industry Meaningful In College are offered at Lehigh University, Michigan Technological University and Rowan University. The Engineering Clinics at Rowan ${ }^{2}$ are offered in the sophomore year. The Integrated Product Development program at Lehigh ${ }^{3}$ and The Enterprise Program at $\mathrm{MTU}^{4}$ are capstone projects in their four-year programs. The Lehigh teams of students in engineering, industrial design and business produce prototypes and business plans in collaboration with industry partners. At MTU, The Enterprise Program option allows engineering students to work with industry partners in student-run companies or "enterprises" that exist beyond a semester. As Lehigh and MTU illustrate, industry partners can be integrated into the program. 
Reengineering Makes Industry Meaningful In College is a replicable, cost-effective model that can be adapted to a varying number of semesters and integrated into a variety of technical programs and college settings.

\section{References}

1. Essential workplace skills. Tech Prep at Illinois Valley Community College, Oglesby, IL http://www.ivcc.edu/techprep

2. Engineering Clinics. Rowan University, Glassboro, NJ. http://www.rowan.edu/colleges/engineering/clinics

3. Integrated Product Development. Lehigh University, Bethlehem, PA. http://www.lehigh.edu/ipd/programs

4. The Enterprise Program. Michigan Technological University, Houghton, MI. http://www.enterprise.mtu.edu

DORENE PEREZ, the Program Director/Instructor of CAD/CAE at IVCC, was one of the MIMIC program originators. A co-leader of the Tech Prep team, she has been recognized for her pioneering in the development of online courses. She is participating in a National Science Foundation funded revision of the CAD program at Moraine Valley Community College. Before teaching, she served five years as a CAD manager in industry.

JIM GIBSON is the Program Director/Instructor of Electronics. He currently serves as a State Director of the Illinois Association of Electronics and Electrical Educators and has hosted that organization's State Skills Contest. He has extensive industrial experience and continues to consult as a troubleshooter. He holds an M.S. and B.S. in Industrial Technology with a minor in chemistry from Illinois State University.

ROSE MARIE LYNCH, a communications instructor, is co-leader of the college's Tech Prep team and codirector of the Center for Excellence in Teaching, Learning and Assessment. She provides communication training to the MIMIC students. In 1999, she was named Illinois Professor of the Year by the Carnegie Foundation. She holds a Ph.D. in English from Ball State University. 